\title{
DOES MEDICAL EXAMINATION FINDING REVEAL THE TRUTH BEHIND A SEXUAL ASSAULT CASE?
}

\author{
Aloke Mazumder' ${ }^{1}$, Apurba Biswas², Saurabh Chattopadhyay ${ }^{3}$ \\ ${ }^{1}$ Assistant Professor, Department of Forensic Medicine \& Toxicology, Malda Medical College, West Bengal. \\ ${ }^{2}$ Assistant Professor, Department of Forensic Medicine \& Toxicology, Malda Medical College, West Bengal. \\ ${ }_{3}^{3}$ Professor and HOD, Department of Forensic Medicine \& Toxicology, Malda Medical College, West Bengal.
}

\section{ABSTRACT}

\section{BACKGROUND}

Medical examinations of sexual assault cases often do not reveal any injury on the body or private part of a Victim Girl, due to which, at courts, the cases often have to depend on the version of a sexual assault victim for the disbursement of justice. In view of this, a study has been conducted to get an idea of the picture.

\section{MATERIALS AND METHODS}

A retrospective study has been done based on the medical examination reports of 37 Victim Girls who gave informed consent out of total 55 cases reported as cases of sexual assault at Forensic Medicine Dept. of a medical college and study regarding the injuries sustained by victim girls and a relation between sexual assault and injury caused by it has been tried to be evaluated.

\section{RESULTS}

Out of total 37 cases, 24 cases were of age group more than 30 years. Also, it was found that total 08 cases married and 06 unmarried Victim Girls sustained injuries both on body and genitals. From the history given by Victims during examination, it was seen that out of 16 consensual sex cases, married were 04 cases and unmarried were 12 cases.

\section{CONCLUSION}

Absence of genital and bodily injuries on a Victim Girl does not make a genuine case of sexual assault at loss because there lies the provision of giving a statement by a Victim Girl u/s 164 Cr.P.C. in front of a Magistrate which also bears an important value in disbursement of justice by the LD Court. The present study is an effort in finding the actual scenario and a related discussion.

\section{KEYWORDS}

Sexual Assault, Injury, Victims, Section 164 Cr. P.C., Medical Examination.

HOW TO CITE THIS ARTICLE: Mazumder A, Biswas A, Chattopadhyay S. Does medical examination finding reveal the truth behind a sexual assault case? J. Evolution Med. Dent. Sci. 2017;6(1):1-3, DOI: 10.14260/Jemds/2017/1

\begin{abstract}
BACKGROUND
Sexual assault, when occurs, may cause injury over genital or other part of body. In the cases like sexual intercourse for fear of death, injury, blackmail or some other reason like application of drug, etc.(1), where a victim girl cannot resist in spite of her non-consent for the sex, chances of getting injured on private parts or body become less and during medical examinations, no specific injury is reported. The matter is same in cases of previous consensual sex also where a girl may sue her sexual partner later on, as a case of sex accused. But the question of justice does not nullify as there is a provision of submission of a statement by Victim Girl in front of Magistrate regarding the occurrence which is also a valuable exhibit. The statement given to police or court is also a supportive fact that may be considered. The present study depicts the actual scenario.
\end{abstract}

Financial or Other, Competing Interest: None.

Submission 15-12-2016, Peer Review 27-12-2016,

Acceptance 29-12-2016, Published 31-12-2016.

Corresponding Author:

Dr. Aloke Mazumder,

Priyadarsini Apartments,

75/1 Kayasthapara Main Road,

Haltu, Kasba, Kolkata-700078,

West Bengal.

E-mail: aloke94@gmail.com

DOI: $10.14260 / j e m d s / 2017 / 1$

\section{(c) (i) $(9$}

\section{Aims and Objectives}

1. To find out incidences of injuries sustained over genitals or other parts of body of a victim girl of sexual assault.

2. To find out any relation between sexual assault and pattern of injuries.

\section{MATERIALS AND METHODS}

Total 55 cases have been studied who reported to Department of Forensic Medicine \& Toxicology, Malda Medical College, West Bengal, during $1^{\text {st }}$ January, 2015 to $31^{\text {st }}$ December, 2015. Victims of adult age group were considered. A retrospective study has been done based on the medical examination reports of Victim Girls who gave informed consent. A table representing injury and related aspects has been formed. To avoid the disclosure of identity of Victim Girls, the names of police stations specifically have not been mentioned though during calculation cases were counted as per the respective PS.(2) The results were analysed statistically to find out any valid relation between occurrence of injury and the incidence. Total 55 cases reported to department out of which 37 Victim Girls gave consent for medical examination. 
RESULTS

\begin{tabular}{|c|c|c|c|}
\hline \multicolumn{2}{|c|}{$\begin{array}{c}\text { Cases given Consent for Medical } \\
\text { Examination }\end{array}$} & $\begin{array}{c}\text { Cases not given } \\
\text { Consent for Medical } \\
\text { Examination }\end{array}$ \\
\hline $\begin{array}{c}\text { Total } \\
\text { married } \\
\text { cases }\end{array}$ & $\begin{array}{c}\text { Total } \\
\text { unmarried } \\
\text { cases }\end{array}$ & Total & 18 \\
\hline 22 & 15 & 37 & \\
\hline \multicolumn{3}{|c|}{ Table 1. Cases on Consent } \\
\hline
\end{tabular}

\begin{tabular}{|c|c|}
\hline Age in Years & No. of Cases \\
\hline Age $\leq 20$ & 13 \\
\hline Age $21-30$ & 05 \\
\hline Age $\geq 31$ & 19 \\
\hline \multicolumn{2}{|c|}{ Table 2. Cases as per age Distribution } \\
\hline
\end{tabular}

\begin{tabular}{|c|c|c|c|}
\hline $\begin{array}{c}\text { Sl. } \\
\text { No }\end{array}$ & Types of Injury & Married & Unmarried \\
\hline 1 & $\begin{array}{c}\text { Total No. of cases of genital } \\
\text { injuries of recent origin }\end{array}$ & 02 & 02 \\
\hline 2 & $\begin{array}{c}\text { Total No. of cases of injuries } \\
\text { to other parts of the body }\end{array}$ & 05 & 03 \\
\hline 3 & Cases having no injury & 17 & 12 \\
\hline 4 & $\begin{array}{c}\text { Cases having both genital \& } \\
\text { bodily injuries (Excluding } \\
\text { cases at Sl. No. 1 \& 2) }\end{array}$ & 01 & 01 \\
\hline \multicolumn{3}{|c|}{ Table 3. Cases of Injuries } \\
\hline
\end{tabular}

\begin{tabular}{|c|c|c|}
\hline Cases of Consensual Sex & Married & Unmarried \\
\hline 16 & 04 & 12 \\
\hline \multicolumn{2}{|c|}{ Table 4. Cases based on History Given } \\
\hline
\end{tabular}

\section{Statistical Analysis}

\begin{tabular}{|c|c|c|c|}
\hline Study & $\begin{array}{l}\text { Recent Genital } \\
\text { Injury Present }\end{array}$ & $\begin{array}{l}\text { Recent Genital } \\
\text { Injury Absent }\end{array}$ & Total \\
\hline Age $\leq 20$ & $3(23.07 \%)$ & $10(76.92 \%)$ & 13 \\
\hline $\begin{array}{c}\text { Age } 21-30 \\
\text { Age } \geq 31\end{array}$ & $\left.\begin{array}{l}0 \\
1\end{array}\right\} 4.17 \%$ & $\left.\begin{array}{l}5 \\
18\end{array}\right\} 95.83 \%$ & $\begin{array}{c}5 \\
19\end{array}$ \\
\hline \multicolumn{4}{|c|}{ Table A } \\
\hline
\end{tabular}

\begin{tabular}{|c|c|c|c|}
\hline Study & $\begin{array}{c}\text { Recent } \\
\text { Genital Injury } \\
\text { Present }\end{array}$ & $\begin{array}{c}\text { Recent } \\
\text { Genital } \\
\text { Injury Absent }\end{array}$ & Total \\
\hline Marital Status & & & \\
Unmarried & $2(13.33 \%)$ & $13(86.66 \%)$ & 15 \\
Married & $2(9.09 \%)$ & $20(90.90 \%)$ & 22 \\
\hline \multicolumn{3}{|c|}{ Table B } \\
\hline
\end{tabular}

\begin{tabular}{|c|c|c|c|}
\hline Study & $\begin{array}{c}\text { Recent } \\
\text { Genital } \\
\text { Injury } \\
\text { Present }\end{array}$ & $\begin{array}{c}\text { Recent } \\
\text { Genital Injury } \\
\text { Absent }\end{array}$ & Total \\
\hline $\begin{array}{l}\text { Concomitant } \\
\text { physical injury }\end{array}$ & & & \\
\hline Present & $2(25 \%)$ & $6(75 \%)$ & 8 \\
\hline Absent & $2(6.9 \%)$ & $27(93.10 \%)$ & 29 \\
\hline
\end{tabular}

\section{DISCUSSION}

\section{Table 1}

Total 18 cases did not give consent for medical examination for reasons like non-acceptance of procedure of medical examination as explained to them. Few preferred only female medical officers and went to Department of Gynaecology. Consent was "informed" type. During examination it was confirmed that the victim girls were not in a stage of menstruation.

\section{Table 2}

Study group was of age above 18 years. From this table; however, it is seen that $64.86 \%$ cases were above 30 years. Assuming the average age of marriage in Indian scenario, indirectly it can be said that the occurrence of sexual assaults among married women are more. As a result, the chance of getting the finding of so called rupture of hymen becomes naturally less. From the history given also during the medical examination, it has been seen that married women assaulted sexually were having issues of normal delivery from their legal marriage.

\section{Table 3}

For the married women, old healed tear of hymen has not been considered as an injury of recent origin due to the sexual assault as reported. Even hyperaemia of vaginal introitus has also been considered as a recent injury. In cases of the unmarried victim girls, the conclusions of their past experiences to sexual intercourse have been formed based on the signs of deflorations like the presence of old healed tear at hymen, breast changes, thick, dark, exposed and cutaneous regions like Labia Minora. In the study, ${ }^{1}$, such cases have been seen in females who showed high probability of consensual sex with some person against whom the charge of rape has been given when the male sex partner denied to marry the Victim Girl.

\section{Table 4}

During medical examination, history regarding the sexual assault and related previous history of sexual experience was taken which was mentioned in the report. It has been seen that 12 unmarried Victim Girls gave a history of sexual experience with the accused where the accused continued physical relation with Victim Girls in the pretext of marriage, later on as he denied, Victim Girls had to take legal action. In such cases old healed tear of hymen was found in 02 cases and in 01 case recent genital injury was seen, while in rest of the 09 cases no specific genital injury was found but Victim Girls agreed to be examined as a case of sexual assault.

For the 04 married Victim Girls, history available was in spite of marriage they had sexual relation with accused (not the husband of Victim Girl). In all the 4 cases, no recent genital injury could be found. Old healed tear of hymen in these cases has not been considered due to sexual relation with husband.

\section{Interpretation of Statistical Analysis-}

Considering the confidence $95 \%$ and P-Value as normal i.e. 0.05 , the Chi-Square $\left(\mathrm{x}^{2}\right), \mathrm{P}$-Value, is calculated with degree of freedom (dof) as 1 and the respective data of the tables are represented as under - 
Table A.

$\mathrm{X}^{2}=3.1274, \mathrm{P}=0.077$, dof $=1$.

Table B.

$\mathrm{X}^{2}=0.1665, \mathrm{P}=0.638, \mathrm{dof}=1$.

Table C.

$\mathrm{X}^{2}=2.131, \mathrm{P}=0.144$, dof $=1$ no link and

It is seen from the statistical analysis that there lies no specific positive relation between the study points and the chances of occurrence of genital injuries, but it can be also inferred that there is some minimal chance of occurrence of genital injury in lesser age group i.e. age 20 years or below (P-Value as 0.077 which is rather closer to normal P-Value).

The statement given by a Victim Girl in front of Police, Magistrate or the LD Court is a definite valuable option in disbursement of justice. But one cannot deny the option of a Medical Examination report because of its importance in confirming the heinous act and strengthening the prosecutors crossing because the uses of medical evidence in rape cases ${ }^{(3)}$ are - a) to confirm the age of Victim Girls, b) detection of marks of resistance, c) detection of marks of violence on genitals, d) collection of blood/seminal stains, e) evidence of rupture of hymen, f) to find out venereal decease, if any. While conducting the medical examination all these points are kept in mind. Though presence of injury on Victim Girls may be self-inflicted but is an unfair perspective as regards a charge of a heinous crime,(4) medical evidence is a definite proof of rape and its presence or absence can convict or acquit as seen in previous few verdicts (Manjali v Emperor, AIR 1941 Sind 121: 42 CrLJ 715.) (5) but the non-production of a medical report is not fatal, if the other evidence in the case is found believable. (Sheikh Zakir v. State of Bihar AIR 1983 SC 911 :1983Cr LJ 1285 ).

Regarding the consent and rape, it is considered that injury indicates forcible intercourse(6) and if prosecutrix in her evidence states that she had not consented to the act, presumption under Section $114 \mathrm{~A}$ of the IEA is that she has not consented.

Taking in consideration all these aspects, the statement of Victim Girls remains very valuable as has been seen in the case where the conviction of accused was sustained though there were no marks of resistance or injury, nor any corroboration, the Victim Girl's testimony resounded with confidence. (State of Maharashtra v. Prakash Kalgya, Kale, 1989 Cr LJ 1389).

\section{CONCLUSION}

Report of medical examination showing presence of injuries on a Victim Girl of sexual assault is a valuable definite exhibit in Court, but its absence does not make a genuine case at loss. There lies the importance of statement of a Victim Girl u/s 164 Cr.P.C. in front of a Magistrate. In a country like India, the socioeconomic status becomes a huge hurdle for a Victim Girl to go for a medical examination which is hardly available in several places. The limitation at this study, as found, is less consciousness of victim girls who often do not report to police in time, sometimes change their clothing or take a bath which hinders in collecting evidence. In view of all these, a truthful statement of a Victim Girl remains an ultimate weapon for a conviction procedure to continue and there lies the success of judiciary system.

\section{REFERENCES}

[1] Nandy A. Principles of forensic medicine. $3^{\text {rd }}$ edn. London: new central book agency 2012:p 690.

[2] Mathiharan K, Kannan KA. Modi a textbook of medical jurisprudence $\&$ toxicology. 24th edn. Nagpur: Lexisnexis Butterworth Wadhwa 2012:p 663.

[3] Mathiharan K, Kannan KA. Modi a textbook of medical jurisprudence \& toxicology. 24th edn. Nagpur: Lexisnexis Butterworth Wadhwa 2012:p 665.

[4] Baxi P. The medicalization of consent and falsity: the figure of habitué in Indian rape law. Kalpana kannabiran, the violence of normal times 2005.

[5] Mathiharan K, Kannan KA. Modi a textbook of medical jurisprudence \& toxicology. 24th edn. Nagpur: Lexisnexis Butterworth Wadhwa 2012:p 678.

[6] Nandi AK, Nandy S. Indian evidence act, 1872. $6^{\text {th }}$ edn. Kolkata: Kamal Law House 2010:p 846. 